\title{
Alcantara Machado e o novo prédio
}

\author{
Prof Cardozo de Mello Neto
}

\begin{abstract}
Discurso proferido no áto da colocação do retrato do respectivo patrono, na Sala "Alcantara Machado" em 12 de novembro de 1949.
\end{abstract}

De hoje em diante, a exemplo do que se dá nas demais aulas desta Faculdade, os estudantes terão diante dos olhos, nos seus trabalhos escolares, o retrato do patrono da sala, a evocar sempre uma das figuras que mais se hajam destacado, na Congregação de Professores - pela cultura, como Ribas e João Mendes Junior; pela austeridade, como Justino de Andrade; pelo preparo juridico, como Ramalho; pelo esforço, como Rubino de Oliveira; pela eloquência, como Crispiniano, Brasilio Machado e João Monteiro; pela orientação didática, como Dutra Rodrigues e Dino Bueno; pela rigidez da administração, como Pires da Mota; pela influência sobre a Mocidade, como Frederico Steidel; pela combatividade, como Pedro Lessa; pelo amor à Academia, como Amancio de Carvalho; pela evocação das suas "tradições e reminicências" como Almeida Nogueira. Pela primeira aula ouvida de Avelar Brotero; pela escolha do local e instalação dos cursos juridicos, por Arouche Rendon.

Esta é a "Sala Alcantara Machado"

Quem foi ele para merecer tão subida honra, dentre tantos outros de tão alto merecimento, cujos nomes insculpidos nos fastos da Faculdade afloram, nesta hora, aos nossos labios e são mentalmente repelidos, mas que 
oportunidade ainda não houve para serem homenageados, como é de justiça e ha de ser feito?

È o que vos vai recordar, moços da Academia, aquele que teve a ventura de privar, desde menino, com o homenageado e de o acompanhar, de perto, precisamente nos dois momentos culminantes de sua existência,' os em que ele deu tudo que tinha de si, porque o deu por São Paulo, em cujo amor se abrazou pela vida, com um tal arrebatamento e constância que, um dia, com justo orgulho, resumiu-o naquela frase colada para sempre à sua personalidade: "Paulista sou ha quatrocentos anos".

Estamos em 1931.

Alcantara Machado realizava (a confissão é própria), seu mais acalentado sonho: estava nomeado diretor da Faculdade de Direito de São Paulo. Ao mesmo tempo quasi, tinham sido criados os Conselhos 'Técnicos-Administrativos, de tão proficuos resultados. Incluido entre seus membros e por ser o mais moderno, dele fui secretário.

Acompanhei assim, momento por momento, a atuaçăo do novo diretor e posso dar testemunho pessoal (unico membro sobrevivente do $1 .^{\circ}$ Conselho) da obra a que se propoz e efetivamente realizou. A Faculdade não podia materialmente continuar a funcionar, como se encontrava. A tesouraria, sem controle. A biblioteca, um mero armazem de livros bichados e desordenados. Ao edificio, é Alcantara quem narra a Aloysio de Castro, em oficio de 5 de Dezembro de 1931:

"Falta-lhe as condições de higiene reclamadas pela destinação do estabelecimento; falta-lhe uma disposição, que atenda a instalação adequada dos serviços administrativos e ao funcionamento das aulas; falta-lhe aquele minimo de conforto, a que tem direito professores, alunos e funcionários. Não tem uma sala que atenda à exigência de iluminação e cubagem impostas pela higiene escolar. Não tem um numero de salas 
correspondente ao numero de alunos: para uma população média de 950 alunos matriculados existem apenas sete aulas, o que tem obrigado a diretoria a utilizar-se dos corredores e do salão nobre, para a realização de exâmes escritos e orais. Não tem um anfiteatro para lições e conferências. Não tem uma "aula magna" para os atos solenes, digna desse nome: alem de ser de dimensões escassas para comportar a assistência numerosa que ocorre às colações de grau e outras solenidades, o salão nobre é deficientissimo, no que respeita à acustica e decoração. Não tem aposentos para o porteiro; a biblioteca e o arquivo, que já foram incendiadas por mãos criminosas em 1880, estão à mercê de malfeitores, quando cerradas as portas da Faculdade. As telhas estão apodrecidas; os forros, bichados; as calhas, em pessimo estado. Daí, goteiras inumeras e infiltração de aguas pluviais, nas paredes de taipas".

\section{Como proceder?}

Precipitar-se na construção de um novo edifício alhures... para as bandas do Butantan e entregar o velho convento aos "tradicionalistas" que desejavam fazer dele um "museu", deslumbrados de que, mudada a Faculdade, a Ordem de São Francisco teria o melhor argumento juridico para retomar a posse do edificio entregue em 1827, exclusivamente para nele ser instalado o curso juridico de São Paulo?

Ou, como fez o diretor, tratar de reformar, a principio, de reconstruir depois, o prédio?

Só a congregação, informada pelo diretor e Conselho Técnico administrativo, poderia resolver.

Ouvidos os professores, não houve, na época, vóz discordante. Não bastava reformar, era necessário - reconstruir. 
Ricardo Severo, o exímio arquiteto, que com tal arte e engenho se houve que passou a ser desta casa, assim dá conta do assunto:

"O longo e debatido estudo do projeto póde separar-se em quatro problemas, a que foran dadas as respectivas soluções, compreendendo o primeiro o aproveitamento do existente e a construção de dois novos salões em dois pavimentos, sobre o quintal dos fundos, fronteiro ia Rua Riachuelo, e apenas recompondo a fachada sobre o Largo, com uma porta monumental; o segundo, nas mesmas condições, porém acrescentando dois pavilhões nos fundos de sorte a acomodar a biblioteca, sala de leitura, o salão de honra e mais quatro grandes salas para aulas; o terceiro, não de reforma, mas de prédio novo com três pavimentos e novas plantas, porém, com a clausula obrigatoria da permanência inalterável do "Patio das Arcadas"; o quarto e ultimo, segundo o plano anterior, mas com quatro pavimentos, tal como está sendo construido".

E, continúa Ricardo Severo, já agora em conversa conosco, logo após a morte de Alcantara:

"Nunca me foi dada incumbência mais técnicamente dificil: levantar um prédio conservando dois patios, um grande e outro pequeno: o Patio das Arcadas e o do tumulo de Julio Frank".

Quem assim agiu, quebrou o culto do Passado, projetado no Presente, que é a propria razão de ser da Escola do Visconde de São Leopoldo?

Onde está a Faculdade? No mesmo chão em que José Bonifacio, o Moço, ensinou e Ruy aprendeu.

Onde cantou e vibrou a vóz da Mocidade durante um século e onde ela continúa a expandir as alegrias da Ju- 
ventude e a vibrar unissona pela Federação, pela Democracia-social, pela Unidade da Pátria, por tudo quanto é nobre, justo, belo e cristão? Dentro das mesmas e idênticas Arcadas, reproduzidas tal qual sairam das mãos de nossos antepassados.

Onde a Mocidade cultuou e continúa a cultuar a memória do melhor dos amigos dos primeiros estudantes do Largo de São Francisco, sinão no mesmo pequeno patio onde sempre esteve, e ficará, aquele tumulo que é o simbolo da fraternidade academica?

Em que se transformou a velha livraria? Na moderna biblioteca, acrescida, atualizada, catalogada e só então capáz de prestar serviços reais.

Onde está a galeria dos antigos lentes? Distribuida nas salas de aulas e da biblioteca.

Que é que foi destruido e merecesse ter sido conservado?

Nada.

Agora, o segundo e último momento culminante da vida de Alcantara Machado.

Estamos em 1933. O insigne professor conduz, como lider, a bancada paulista, na Assembléia Nacional Constituinte, a bancada (a proposta é dele) eleita sob a legenda "chapa Unica por São Paulo Unido". Escolhido sub-lider entre tantos de maior merecimento, trabalhei com Alcantara dia e noite, durante meses.

O que o lider de São Paulo precisou dispender de arte politica, envolvida numa suave mas inquebrantavel energia, será compreendido unicamente por quem se transportar à época, que ainda era a de 1932.

Alcantara conseguiu vencer, com sua bancada, dentro de um principio, que foi o nosso unico programa: - "São Paulo aqui está na Constituinte, exclusivamente para fazer uma Constituição. Dentro desse propósito, só reconhece 
como adversários aqueles que não quizerem dar uma Constituição do Brasil". E nós a demos.

A medida do merecimento de Alcantara está em Brasilio Machado.

Sómente aqueles que sentiram a influência empolgante, tocando às raias da ditadura intelectual, que Brasilio exerceu na sua época e principalmente dentro desta Academia, é que poderão avaliar o drama que teria sido o daquele moço imberbe e timido que, aos 20 anos incompletos, assentou-se no doutoral, aos pés do Pae.

Para ser alguem por si e não só o filho amado, foi mistér possuir a capacidade de estudo silencioso, a paciência beneditina, a perseverante vontade de vencer de que Alcantara deu mostras.

Para ser diferente de Brasilio, era preciso ter a envergadura intelectual de Alcantara. Ele a teve e para mais.

A Faculdade de Direito de São Paulo revê, com saudade e orgulho, no retrato que ora incorpora ao seu patrimonio,

o "Mestre de Direito, Artista da palavra, Glorificador da terra natal" que foi o "Reedificador deste Predio". 